\title{
PERTANGGUNGJAWABAN HUKUM PEJABAT PEMERINTAHAN TERHADAP TINDAK PIDANA KORUPSI DALAM LINGKUP TUGAS DAN KEWENANGAN ADMINISTRATIF
}

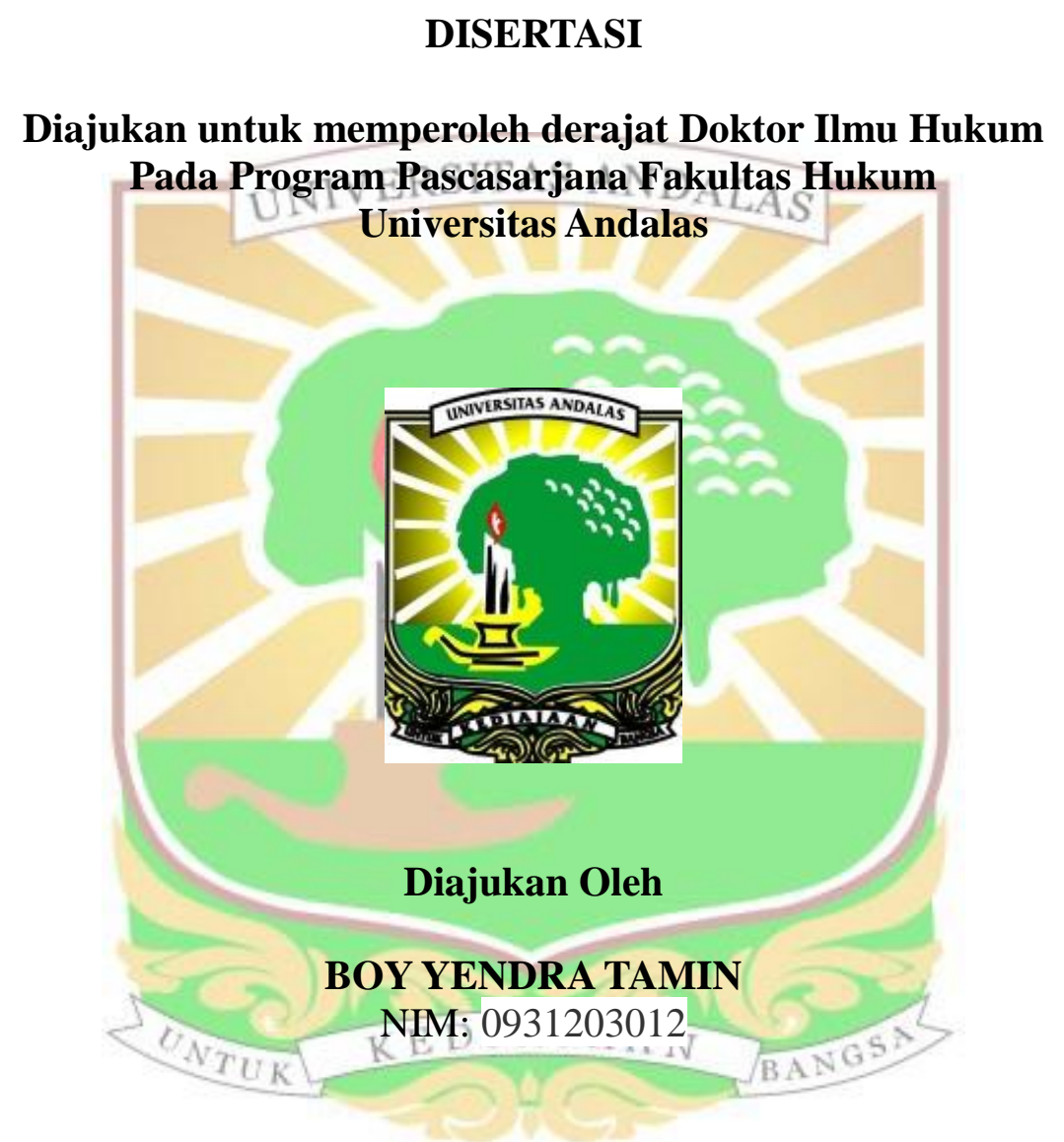

Promotor :

Prof. Dr. H. Elwi Danil , SH. MH

Prof. Dr. Yuliandri, SH.MH

Prof. Dr. Saldi Isra, SH. MPA

PROGRAM DOKTOR ILMU HUKUM

PROGRAM PASCASARJANA FAKULTAS HUKUM

UNIVERSITAS ANDALAS

PADANG

2017 


\begin{abstract}
ABSTRAK
Pelaku tindak pidana korupsi di Indonesia dominan dari kalangan pejabat pemerintahan dan dihadapkan pada pertanggungjawaban hukum yang tidak berkepastian karena ada area abu-abu antara hukum administrasi negara dan hukum tindak pidana korupsi. Permasalahan dalam penelitian ini adalah; (1) Mengapa diperlukan pertanggungjawaban hukum yang jelas bagi pejabat pemerintahan dalam menjalankan tugas dan kewenangannya; (2) Apakah kebijakan dan kesalahan administratif pejabat pemerintahan dalam menjalankan tugas dan kewenangan dapat dijadikan tindak pidana korupsi; (3) Apa tolok ukur untuk menentukan perbuatan melawan hukum dan penyalahgunaan kewenangan pejabat pemerintahan sebagai tindak pidana korupsi dalam menjalankan tugas dan kewenangan. Penelitian ini merupakan penelitian hukum (legal Research) dengan menggunakan metode pendekatan konseptual (conceptual approach), pendekatan perundang-undangan (statute approach) dan pendekatan kasus (case approach). Teknik pengumpulan data melalui studi pustaka dan dokumenter terhadap bahan hukum yang terkait dengan substansi penelitian. Data dianalisis secara kualitatif. Hasil penelitian terhadap permasalahan pertama tentang keperluan pertanggungjawaban hukum pejabat pemerintahan yang jelas dalam menjalankan tugas dan kewenangannya disimpulkan pembentukan UU Pemberantasan Tindak Pindana Korupsi (UUPTPK) Nomor 31 Tahun 1999 jo UU Nomor 20 Tahun 2001 dibentuk dan disusun dalam ketiadaan UU Administrasi Pemerintahan (UUAP) yang menjadi dasar dan payung hukum pejabat pemerintahan dalam mengambil keputusan dan tindakan dan sekaligus sumber penyebab dualisme pertanggungjawaban pejabat pemerintahan dalam melaksanakan tugas dan kewenangannya. Undang-Undang Administrasi Pemerintahan telah memperkenalkan perbedaan antara kewenangan dan wewenang sehingga norma hukum tindak pidana korupsi Pasal 3 UUPTPK tidak sesuai lagi dengan konsep pertanggungjawaban pejabat pemerintahan dalam lingkup tugas dan kewenangannya. Dalam praktik peradilan penerapan Pasal 2 dan Pasal 3 UUPTPK cenderung diterapkan dalam jabatan dan bukan karena jabatan. Terhadap permasalahan kedua tentang kebijakan pejabat pemerintahan dan kesalahan administratif disimpulkan tidak ada ketegasan hukum yang menyatakan bahwa kebijakan dan kesalahan administrasi tidak dapat dipidana. Terhadap permasalahan ketiga disimpulkan, UUPTKP tidak memiliki pengertian yang eksplisitas atas menyalahgunakan kewenangan dan tidak mempunyai tolok ukur sendiri untuk menentukan perbuatan pejabat pemerintahan sebagai tindak pidana korupsi dan sekaligus melahirkan inkonsistensi dan ambiguitas tafsir atas perbuatan melawan hukum dan penyalahgunaan kewenangan sebagai unsur tindak pidana korupsi. Untuk itu, tolok ukur untuk menentukan perbuatan melawan hukum sebagai tindak pidana korupsi, adalah tolok ukur subjek, tolok ukur klasifikasi perbuatan dan tolok ukur residu. Tolok ukur untuk menentukan perbuatan menyalahgunakan kewenangan adalah tolok ukur kapasitas subjek, tolok ukur objek hukum dan tolok ukur residu. Tolok ukur tersebut merupakan titik temu antara hukum administrasi negara dan hukum pidana korupsi dalam meletakan pertanggungjawaban hukum bagi pejabat pemerintahan dalam lingkup tugas dan kewenangan.

Kata kunci: Pertanggungjawaban Hukum, Pejabat Pemerintahan, Tindak pidana korupsi
\end{abstract}




\begin{abstract}
The perpetrators of corruption in Indonesia are dominant among government officials and are faced with uncertain legal liability because there is a gray area between the state administration law and the law of corruption. The problems in this research are; (1) Why needed a clear legal liability for government officials in the exercise of those powers and duties; (2) Are policies and administrative mistakes of government officials in performing their duties and authority can be made corruption; (3) What is the benchmark for determining unlawful acts and abuse of authority of government officials as a criminal act of corruption in carrying out its duties and authorities. This research is a legal research using conceptual approach, statute approach and case approach. Data collection techniques through literature and documentary study of legal materials related to the substance of the study. Data were analyzed qualitatively. The study of the first problem of the need forlegal accountability of government officials were clear in their official duty inferred Law on Combating Criminal Offenses of Corruption (UUPTPK) No. 31 of 1999 in conjunction with Law No. 20 of 2001 established and organized in the absence of Law on Government Administration (UUAP) which became and the basic legal framework of government officials in taking a decision and once the source of the cause of the dualism of government officials accountable in carrying out its duties and authorities. Government Administration Act has introduced a distinction between the authority and the authority so that the legal norms of corruption Article 3 UUPTPK no longer compatible with the concept of accountability of government officials within the scope of duties and authority. In the judicial practice, the application of Article 2 and Article 3 of UUPTPK tends to be applied in position and not because of position. On the second issue concerning the policy of government officials and administrative errors it is concluded that there is no legal assertion that policy and administrative error can not be criminalized. The third issue to be concluded, UUPTKP do not have the sense of explicitly turn on misuse of authority and does not have its own benchmarks to determine the actions of government officials as corruption and gave birth to inconsistencies and ambiguities of interpretation on tort and abuse of authority as an element of corruption. To that end, benchmarks for determining tort as corruption, are the benchmarks subject, benchmarks classification of acts and benchmarks residue. A benchmark for determining abuse of authority is the benchmark of the subject's capacity, the benchmark of the legal object and the residual benchmark. The benchmark is a meeting point between the law of state administration and the criminal law of corruption in placing legal liability for government officials within the scope of duty and authority.
\end{abstract}

Keywords: legal liability, Government Officials, Corruption 